\title{
Leading Islamic University Through Excellent Higher Pesantren: Challenges, and Strategies in Integrated Curriculum Development
}

\author{
Muhammad Thoyib \\ IAIN Ponorogo, East Java, Indonesia \\ thoyib@iainponorogo.ac.id \\ Muhammad Nurdin \\ IAIN Ponorogo, East Java, Indonesia \\ nurdin@iainponorogo.ac.id \\ M. Widda Djohan \\ IAIN Ponorogo, East Java, Indonesia \\ widda@iainponorogo.ac.id
}

\begin{abstract}
Along with the pace of globalization, and the severity of educational competitions, not a few actors of Islamic higher education tried to integrate two 'educational entities' (university and pesantren), in an integrated education curriculum system. Some were successful, but not a few was failed. This qualitative research article is based on interactive model data analysis technique that aims to 'initiate' the efforts of integrated curriculum development model of excellent higher pesantren at UII Yogyakarta, considering its good institutional achievement, so it should be the pilot project of the integration effort. This research concluded that the indigenous values in integrated curriculum development based on its excellent pesantren are to be oriented at the value of establishment of a 'progressive-inclusive-integrative' scholars candidate. The challenges of its integrated curriculum development include the alignment of synergical idea of university values and modern pesantren; institutionalization of university and pesantren policies; and integrating the curriculum products of university-based pesantren and community service. While, the strategies of its integrated curriculum development are implementing a top down and bottom up approach that involve all its stakehoders through a forum for feasibility of pesantren curriculum development that supported by phases that are determination of the pesantren curriculum enforcement area, development procedures; curriculum implementation; and evaluation results. However, it still needs strengthening 'the outsider's perspective', especially from the users of its pesantren curriculum products in order to be able more adaptive to global needs as the idea of Beauchamp
\end{abstract}

Keywords: Integrated curriculum development; challenges; strategies; excellent higher pesantren 


\begin{abstract}
Abstrak
Seiring dengan derasnya laju globalisasi, dan sengitnya kompetisi pendidikan, tak sedikit pelaku pendidikan tinggi Islam mencoba memadukan dua 'entitas pendidikan' (perguruan tinggi dan pesantren), dalam sebuah sistem kurikulum pendidikan yang terintegrasi. Sebagian ada yang sukses, tapi tidak sedikit pula yang gagal. Tulisan hasil penelitian kualitatif dengan teknik analisis data model interaktif ini bertujuan untuk 'menginisiasi' upaya integrasi model pengembangan kurikulum pesantren unggulan berdimensi universitas di UII Yogyakarta, mengingat prestasi institusionalnya yang baik, sehingga layak menjadi pilot project upaya integrasi tersebut. Penelitian ini menyimpulkan bahwa: nilai-nilai indigenous (kekhasan) dalam pengembangan kurikulum integratif berbasis Pesantren unggulnya bersendikan pada nilai yang berorientasi pada pembentukan calon cendekiawan yang 'progresif-inklusifutuh'. Tantangan pengembangan kurikulum integratifnya meliputi; penyelarasan sinergisitas gagasan nilai-nilai universitas dan pesantren modern; institusionalisasi kebijakan universitas dan pesantren; serta pengintegrasian produk kurikulum pesantren berdimensi universitas dan social community. Sementara itu, strategi pengembangan kurikulum integratifnya menggunakan pendekatan top down dan bottom up yang melibatkan seluruh civitas akademikanya melalui forum pengembangan kelayakan kurikulum pesantren unggul yang didukung dengan sejumlah tahapan diantaranya adalah penetapan wilayah pemberlakukan kurikulum pesantren, prosedur pengembangan, pengimplementasian kurikulum, serta hasil evaluasi kurikulumnya. Namun begitu, perlu penguatan 'outsider perspektif, khususnya dari pengguna produk pesantrennya agar produk kurikulumnya dapat senantiasa adaptif terhadap kebutuhan global sebagaimana gagasan BeauchampPendahuluan
\end{abstract}

Kata Kunci: Pengembangan kurikulum integrative; tantangan; strategi; pesantren tinggi unggulan

\title{
A. Introduction
}

The existence of university and pesantren are two educational institutions that have many differences. On the one hand, the university has the advantage of its rationality and experimentation. While the pesantren according to Azra (Azra, 2012) is a traditional world of Islam that is a world that inherits and maintains the continuity of Islamic traditions developed by scholars from time to time, not limited to certain periods in the history of Islam serves as a national adhesive, both culturally and institutionally. The function of higher education is in line with the University mission formulated by Reeves (Reeves, 2017) and Lambert (Lambert, 2019), that is teaching, research, and community service in the form of professional 
development. Therefore, it is not surprising if several decades lately, a number of Islamic Higher Education (PTKI) in Indonesia develop its university by establishing higher pesantren as an amplifier of its existence as an effort to produce prospective moslem scholars in the future.

With the rapid development of science and the opening of life with mankind, the responsibility of a scientist will have a new dimension of devotion to all mankind. So in that context, according to Sukarji and Umiarso (Sukarji and Umiarso, 2014), the University of the future must establish a "network" with regional and international institutions not only because of the universal science, but also the global workforce of the scientist. On the other hand, historically, the tradition of pesantren not only contains the meaning of Islamic studies, but also the authenticity of Indonesia that is so distinctive (Indonesian indigenous), because of its plurality, both from institutional and socio-cultural dimention. Meanwhile, Bruinessen (Bruinessen, 1995), and Asrofah (Asrofah, 2009) say that pesantren is a model of Islamic education adopted from the education system in the Middle East that is able to provide a variety of social community differences.

In line with this, Wahid (Wahid, 1984) ever strengthened that the function of pesantren, because of the form and nature of it, is as a religious education (Tafaqquh fial-Din), religious social, and broadcasting religion, with its fiqh-sufistic teaching style that is completed with the orientation of here after spirit (al-jiiah al-ukhrawiyyah). In other words, the Islamic university with the concept of higher pesantren will become a more dynamic and transformative 'lighthouse project ' in realizing the future excellent moslem scholar in Indonesia. The effort of strengthening Islamic higher education with the existence of pesantren, has been initiated and developed by the UMS by establishing Pesantren Shabran in the 1984's, as well as UIN Maulana Malik Ibrahim Malang by establishing Ma'had Aly in the year 2000's that is running until today. But, of course, with their respective dynamism, including its advantages and disadvantages.

In the context of present, along with the increasing pace of globalization and educational competitions, as well as the challenge of multiculturalism as it develops today (Sulistyo, 2015) is not a second of the 'Entities' (university and higher pesantren) try to be combined by many actors of Islamic education in an integrated education curriculum system, both in private and state Islamic universities, as in UII Yogyakarta, and so forth. Some were successful, but not a few was failed. It is based on research results in the year 2016 which identifies that efforts for 'integrating' college-based pesantren in many Islamic colleges are only $37 \%$ of the 55 colleges in the areas of Java, Sumatera and Kalimantan which success, both from 
the curriculum and its weaknesses, the rest is actually seen to fail. It is based on a number of failure indicators; (1) The curriculum of pesantren developed has no strong correlation to the development of its higher education, so it is impressed to walk on its own. (2) Many of its human resources are not yet prepared in the sciences to guide and implement a designed curriculum, as well as (3) Coordination lines tend to be not related, so there is not infrequent miscommunication, and conflict between the existing stakeholders (Hardian, 2016).

In that context, a research on the existence of excellent higher pesantren at Indonesian Islamic University (UII) of Yogyakarta, becomes relevant and important thing with a number of rational considerations of the selection of research objects as follows ("Document of UII Yogyakarta," 2017). First, UII Yogyakarta is an Islamic university that has a commitment and a vast international network background. This is evidenced by the frequent international seminar program and consolidation involving multicultural figures-pluralists of European and Asian countries such as Canada, UK, Malaysia and Singapore. Moreover, the institution has figures that historically appreciated the diversity of Indonesia, as well as Moh. Hatta, Wahid Hasyim, Tengku Cik Ditiro, Mahfud MD, and so on. Although, institutionally, UII has not been compared to the 100 top universities of the world, especially those are in the Asian region, such as the National University of Singapore (NUS) which is a public university with a large fund from its government. However, the presence of UII as a private university that gives full scholarship to the students who are in its excellent higher Pesantren deserve to be inspiring university in its efforts to produce the prospective moslem scholars. Its efforts are proven by its alumnus have contributed a lot by becoming a lecturer in PTKI/PTU, judges, teachers, diplomats, entrepreneurs, LIPI researchers, and so on.

Secondly, UII Yogyakarta has an excellent higher pesantren that has been well integrated, both from the curriculum and its humidity. In the UII, where the excellent higher pesantren program has existed since the year 1996, where students who take and pass the selection of the excellent higher pesantren, are obliged to use foreign languages (Arabic and English) in its lecturing. Therefore, the excellent higher pesantren has a strict selection standards, such as must have an active Arabic and English proficiency marked with ITP TOEFL score of at least 450 , and so on.

Third, it is from the side of academic and non academic achievement. The excellent higher pesantren of UII Yogyakarta, has gained many national and international achievements. As it has been, since 2000-2018, it has always been able to send delegates in international student exchanges, both in the Middle East such as the Global Youth Moslem Leadership and The International Debate Forum for Islamic Students in Morocco, Jordan, Medina and UAE, 
as well as to Europe and America. In the mid-2000-2018 ago, the institution was successful to deliver the students to the national MTQ Champion, both in the field of syarhil, student writting competition, and so forth.

This research is a field research in a qualitative descriptive form where the research seeks to describe the phenomenon of integrated curriculum development for its excellent higher pesantren. This research uses the phenomenological approach which aims to describe the phenomenon occurring (Bogdan and Biklen, 1996). This approach is a great way to reveal and interpret various related and influential activities in the application, closely related to (1) The indigenous values of the integratedcurriculum development, (2) The strategies of integratedcurriculum development, and (3) The Challenges of integrated curriculum development. This research data is obtained from data sources through procedures (Arikunto, 2008). Of course, the focus of this research is not separated from the shortcomings that need to be continuously enhanced by its higher pesantren in the midst of its excellence.

\section{B. Discussion}

\section{The Brief History of Excellent Higher Pesantren at UII Yogyakarta}

The spirit behind the founding of Indonesian Islamic University (UII) of Yogyakarta on July 8, 1945 (27 Rajab 1364 H) was the desire to print a national cadre of Indonesian Muslims, who were welcoming their independence. In the ideas of its founders who later crystallized in historical documents about UII. The purpose was that it was expected to be able to produce intellectual Muslims who were skilled and charitable. In other words, UII was established to help educate the nation's cadres who have souls to report on the basis of integrity of faith and scholarship. So that they can produce special scholars as Islamic higher education products.

With the spirit that was carried out when establishing the UII, the organizers of education and teaching at the university strived to build the ability to organize Islamic higher education in educating, teaching, and developing knowledge and values that are sourced from divine revelation, in order to give birth to leaders, people and nations that are able to show the principles of Islam as modern principles that bring mercy to all nations and humanity. But in reality, after the it contemplated and received input from the community, it was realized that until now, UII had not fully been able to realize the ideals of its founders to print a nation cadre or Muslim intellect specifically producted by UII, so the public was also less able to see special characteristics that distinguish between its graduates and other tertiary education graduates. Therefore, more concrete steps are needed to approach what was ordered by the founders of UII. 
In addition, it was also realized that the declaration of UII's Catur Dharma which prioritized Islamic da'wah as the dominant element in crystallizing the mission of Indonesian Islamic University was the responsibility of the entire UII academic community and alumnus. This mission wants UII to produce Muslim intellectuals who have scientific integrity and Islamic personality rooted in monotheism. The interconnectedness of worldly science and spiritual needs to be built in a strong bond.

Based on these hopes and thoughts as expressed above, the Indonesia Islamic University of Yogyakarta which was initiated by Prof. Zaini Dahlan, MA., Prof. Dr. Mahfud $\mathrm{MD}$, and so on, then offered excellent student recruitment programs where participants who passed the selection would be fostered intensively in an Excellent pesantren institution, which was combined with regular undergraduate education (S-1) in the faculties at UII, in accordance with their interests and abilities, so that it is expected that later it can produce graduates (output) as aspired by it.

This program in the first year (academic year on 1996/1997) was intended for the Faculty of Sharia and the Faculty of Tarbiyah (now the Faculty of Islamic Studies), while for the second year onwards, it was opened to all faculties in the UII environment. Due to the limited facilities and infrastructure available, until now its excelent higher pesantren is only intended for special students. However, along with the development of time and the need to respond to scientific challenges that are increasingly accommodating, in 2007 a flagship program for its women's excellent higher pesantren was established at the Kaliurang Yogyakarta which is integrated campus.

The initial idealism of the opening of excellent higher pesantren program was the production of graduates who would return and serve in their respective regions. But in the course of time, this initial idealism underwent a shift and the graduates were given more flexible service space, without the need to return to their home regions. This policy was taken with a variety of considerations, including in order that the implementation of service can be carried out more effectively and optimally, as well as providing clear benefits, both for the community (people) in general and for the environment of its own institutions. This is proven by the many alumnus who are the pioneers of the community with various professions as lecturers, judges, principals, teachers, diplomats, and so on with a variety of national and international achievements. Until now, there are 85 students in excellent higher pesantren of UII Yogyakarta, 40 of them are male and 45 are female students. 


\section{The Indigenous Values in the Integrated Curriculum Development of Excellent Higher Pesantren at UII Yogyakarta}

Subtantively, the development of integrated curriculum is interpreted as an effort to design the education improvement that summarizes all the learning experience provided for students in an educational institution. The draft is prepared with the intention of guiding the executive education, in the process of providing guidance to the students, and achieving the education objectives (Pratt, 2019). In simple language, the development of integrated curriculum can be understood as an effort to update the learning guidelines of an educational institution that covers the overall needs of students.

In the implementation, indigenous values (peculiarities) in the development of the integrated curriculum of its excellent higher pesantren as the findings of the researchers, subtantively beyond to the value of UII's Dharmabakti in which contains 5 main values: (a) Rahmatan lil'alamin; (b) has superiority; (c) has scholarly competence; (d) Islamics; and (e) Da'wah Islamiyah are being the values that academically has become a platform for its excellent higher pesantren as well as the soul of its academic-spiritual higher Islamic education ("Document of UII Yogyakarta," 2017). The academic spirit in the perspective of researcher, is a reflection of the height of its scholarship that wants to be built and developed by its excellent higher pesantren. While the spiritual spirit is a reflection of its Islamic-scientific foundation that is based on the value of ' exoticism ' the ever-expected will be able to bring universal peace.

The importance of accommodating "internal value" as well as 'external value' of Islam in its excellent higher pesantren is aligned with the view of Indian muslim scholars, Ajijola (Ajijola, 2012) where in his monumental book, Restructure of Islamic Education, which Confirms the importance of integrated values in the development of Islamic educational institutions which is capable to integrate the islamic values and the values of global excellents is that develops along with the changing times. In other words, the fifth value of specificity developed in the integrated curriculum of its excellent higher pesantren is a par excellance 'academic synthesis', which not only speaks of the importance of Islamic contemporary values, and global challenges but as well as the contribution of Islam to the global community (global society), especially at the value of Rahmatan Li 'Alamiin and its Da'wah Islamiyah which is so inclusive that is manifested in the form of community devotion multiculturalism in accordance with the science field owned by the students, both in the field of religion, economy, technology, law and so forth. 
In a more dynamic-subtantive context, the fifth main values of UII's excellent higher pesantren is specifically oriented to the formation of people who have a 'progressive-inclusiveintegrative' personality because it is supported by excellence and competence in the field of religious thinking, science, skill, development of research with the excellent stability of aqidah, spiritual depth, and moral nobility as its excellent higher pesantren vision-mision. This further situation solidified its excellent higher pesantren as one of the 'destined' students to prepare the nation's moslem scholars who not only have the competence in one scholarly knowledge, but at the same time in a number of social science and Islamic studies together with additional reinforcement in the field of foreign languages (Arabic and English) as a major supporter of the communicative value of its teaching.

The integrated curriculum development is by resting on the urgency of foreign languages in its excellent higher pesantren from the recruitment process of prospective students, lecturing process until the final duty product that has been designed systematically by its excellent higher pesantren in collaboration with the University to strengthen the existence of the higher pesantren and UII as an institution of Islamic higher education that has been raised through quality of its profile is in the archipelago, both as a lecturer, a judge, a teacher, and so on. And an international achievement that is almost every year achieved by the students, both in the form of competitions in the international level as well as a further study scholarship of S2/S3 abroad such as to the United Kingdom, Netherlands, Australia, Japan, and so on (Suyanto, 2018). The success of this integrated curriculum development, borrowed the language of Hardian (Hardian, 2016), 'as a genuine curriculum of excellent pesantren, which is capable of covering the challenges of globalization.'

The consequence of the 'first' main value of the UII's excellent higher pesantren is that the 'Rahmatan Lil 'Alamiin' appears also in the implementation that not only puts moslem scholars as its manpower but also non moslem have professional competence in certain field such as christology courses and research as a form of 'the value of inclusive multiculturalism'. This is evidenced by the coming forth of a number of its higher pesantren's alumnus as lecturers in the field of religious interdisciplinary who understand the importance of sustainability. In the simple way, the values and orientation of integrated curriculum development in its excellent higher pesantren can be described through the chart as follows: 
Figure 1. Values and Orientation of Integrated Curriculum Development at UII's Excellent Higher Pesantren

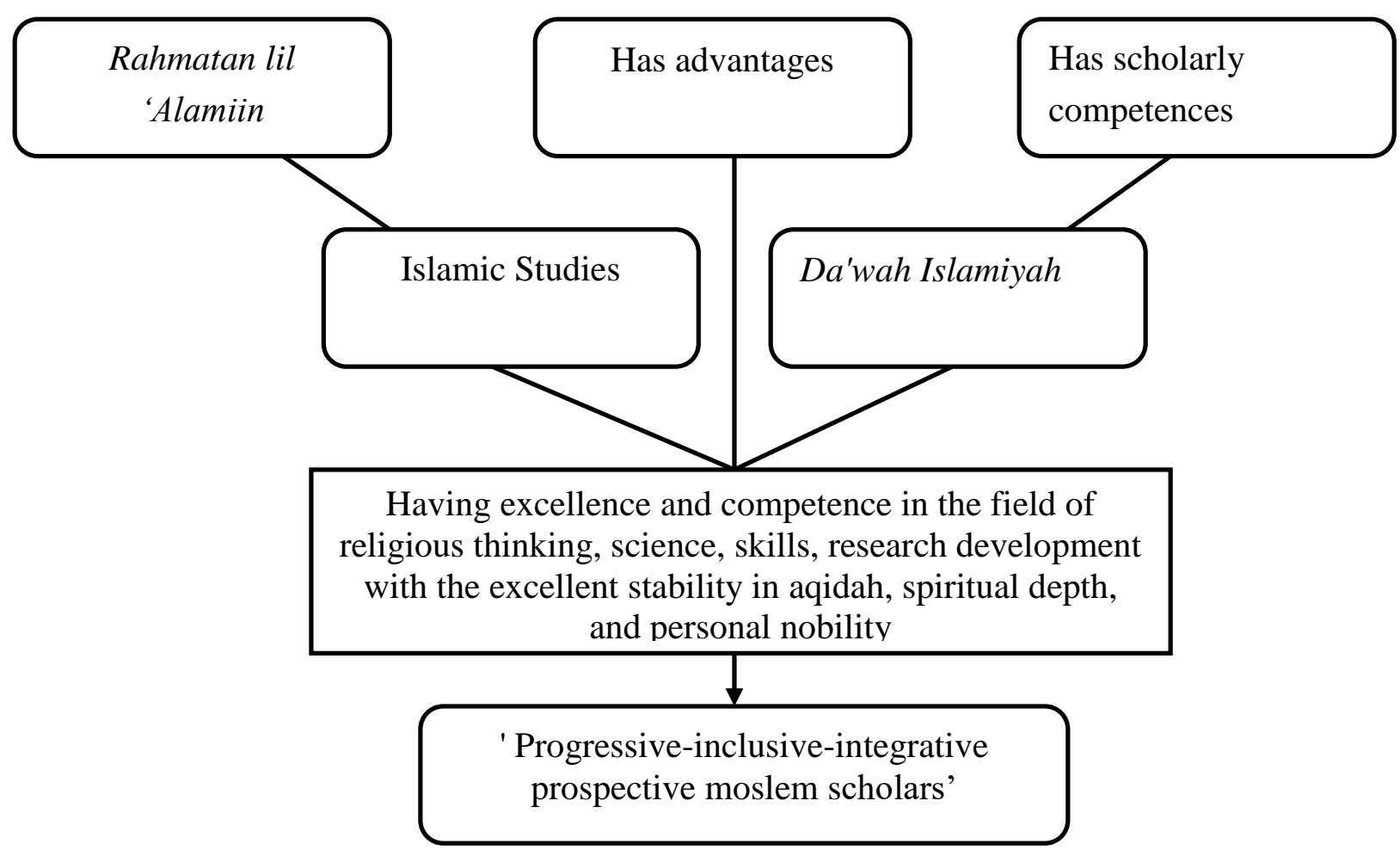

Academically, in a researcher's perspective, these values can be held into two different dimensions, but strengthening each other's existence:

In its orientality macro dimension, values such as Rahmatan Lil 'Alamiin affirm how much of the commitment of its excellent higher pesantren in an effort to continue initiating the birth of moslem scholars who remain concerned about the 'wave', both national and international level.

On the value of Khairu Ummah and Tafaqquh Fi al-Din asserted the other side of the orientation of its Islamic higher pesantren flagship that wants the birth of future moslem scholars who have certain skills (specifications) in the field of Islam, namely 'Islamic studies'.

The analysis of researcher, in line with the thinking of Furchan (Furchan, 2015), which confirms the scientific competence of Islamic higher education, one side is expected to be able to bridge the 'interests of the world', but on the other hand must have distingtion and uniqueness of the Islamic higher education. Or in the language of the researcher, the integrated 
curriculum development is worth 'local wisdom' with the dimension of 'global responsibility'. In the same context, Sparapani, E.F and David M. Callejo Perez (Sparapani and Perez, 2015), in their article "A Perspective on the Standardized Curriculum and Its Effect on Teaching and Learning", provide strengthening that the value inherent in the curriculum management will add an ideal construction of the 'profile' of the institution itself as well as social branding that will always be remembered by the community, especially the users of their education.

\section{The Challenges of Integrated Curriculum Development in UII's Excellent Higher Pesantren}

The challenge is the dynamics of contestation subtance in any field. No exception in the field of education. With always the presence of dynamic challenges, is that educational institution continues to grow, especially in the context of globalization and modernity that is increasing rapidly today. Bill Gates confirms that in his scientific language as 'modernizing the world civilization' which not only inspires the birth of science but more than that, revamps the increasingly inclusive governance of the human social life (Furchan, 2015). Or in the view of Ziemek (Ziemek, 1992), educational institutions included in this development of pesantren in the realm of university will having metaphorfosis as the 'balancing' as well as 'refinements' of the university's own existence, especially about value aspects of its academic organization structure.

One of the successes key or failures of an educational institution development relies heavily on the 'heavy-tigh' challenges that it faced, no exception to UII Yogyakarta. In the context of challenges of the integrated curriculum development in its excellent higher pesantren, there are at least 3 major challenges that have occurred namely (Suyanto, 2018):

a. The alignment of synergical idea of university values and modern higher pesantren in particular about the input profile of student, the profile of its graduates, as well as material profiles of higher pesantren curriculum;

b. Institutionalization of university and excellent higher pesantren policies that are ultimately oriented towards the standards of policy determinant of its higher pesantren, curriculum implementation and procedures for its implementation between university values with dimension of its higher pesantren, such as the grades of higher pesantren that can be closed to the university level, etc. involving various parties with diverse ' Islamic ideology '; 
c. Integrating the curriculum product in the dimension of university and social community that is oriented towards the form of community devotion that must be followed by the student that has been declared to pass the S1 level, as well as the obligation to follow the academic and non academic competition as the 'proof of quality' of its excellent higher pesantren product.

These three challenges have become the 'debatable academics' that occur all the time among the leadership of excellent higher pesantren and university, especially vice-rector 1 and 3 who have been coordinating the formulation of policy early in the inception of its flagship that is being the platform as part of the 'identity' of science, and Islamic values as well as multiculturalism that develops in UII Yogyakarta. Therefore, 'color ideology' of its excellent higher pesantren must stand on all the values of existing multiculturalism, both NU, Muhammadiyah, Persis, Nahdhatul Wathon, and so on. The identity of the well-managed scientific and ideology multiculturalism increasingly makes UII in particular to become an competitive and excellent institution. It is in line with the affirmation of Reeves (Reeves, 2017) in The Commander's Guide to Standars: A Blueprint for Educational Equity and Excellent that a quality of educational institution, essentially is not departing from the dimensions of a single aspect, but it's precisely born and developed from the managed aspects that support the institution precisely and maturely.

Broadly, the challenges that are faced by UII's excellent higher pesantren can be described through the following image:

Picture 2. The challenges of Integrated Curriculum Development in UII's Excellent Higher Pesantren

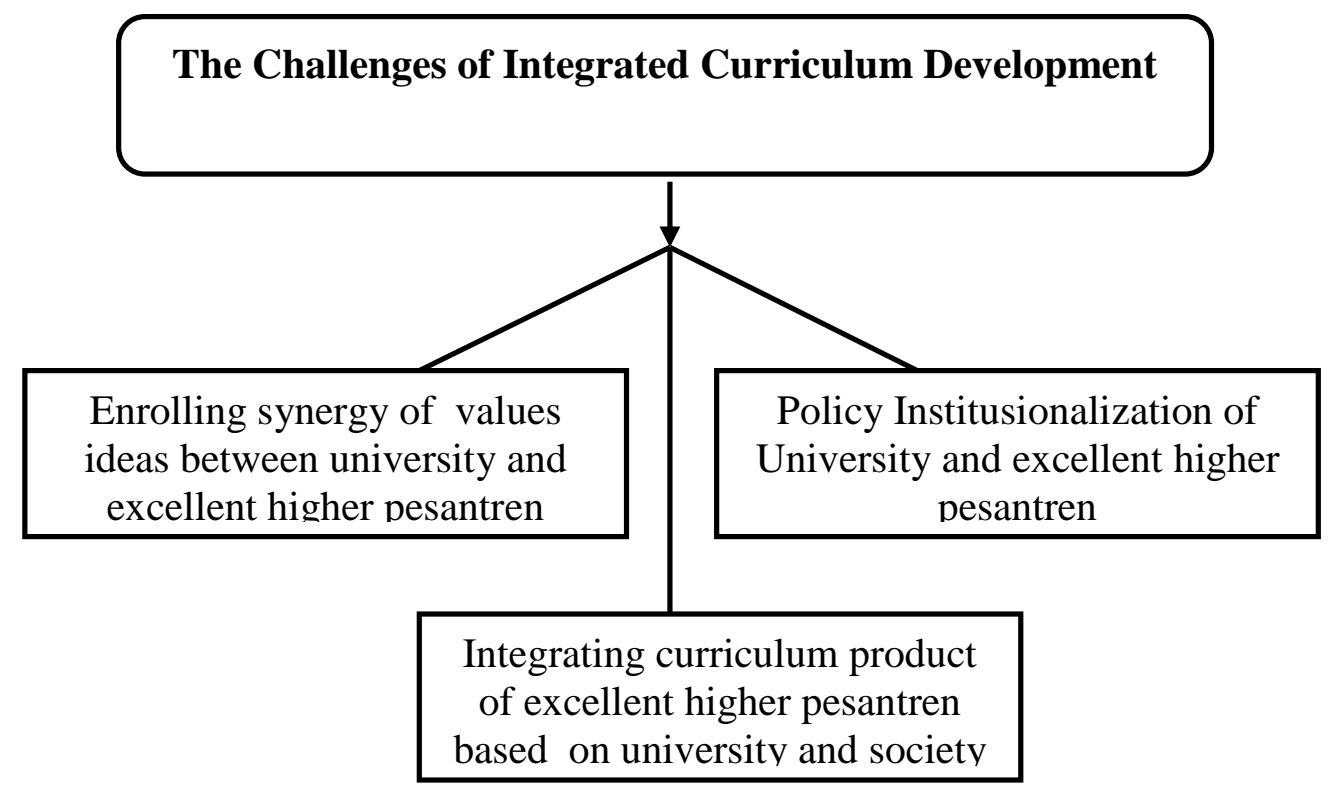

Edukasia: Jurnal Penelitian Pendidikan Islam 
Looking at sketches of various challenges in the integrated curriculum development of its excellent higher pesantren, there are actually certain points that are focused priority at the same time as 'differentiator' from university in general. It is a challenge for the modernization of science, to as the 'adhesive' of Islamic values, so that its Islamic higher education has always resulted in a scholarly knowledge that is well-established in the midst of competition in the world of education Increasingly complex and devastating height today.

\section{The Strategies of Integrated Curriculum Development in UII's Excellent Higher Pesantren}

The strategy of integrated curriculum development in its excellent higher pesantren as the findings of researcher can be said in its implementation, using top down and bottom up approachs as well as involving a number of parties, namely the rectorate, director, curriculum experts, caregivers, lecturer representatives, students and alumnus (Anas, 2018). The involvement of a number of strategic parties is an important point in conducting 'improvement' of the curriculum development efforts conducted by UII's excellent higher pesantren. It is relevant to the equivalent of Ballante's opinion (Ballantine, 2017) which reveals that the subtantive value of the importance of accommodating attitudes in education development, especially curriculum at the level of education unit will open up opportunities for a creative and innovative educational program that is not only capable of answering global competition challenges, but more than that will be able to make a broader contribution (socialacademic highlights). And this is what is currently experienced in the massive contribution of its excellent higher pesantren, which one of them through the development of leading higher pesantren seriously.

The contributions to the design of currculum development in its excellent higher pesantren can be seen also from the side of strategic role of alumnus scattered throughout the archipelago where they actively provide contribution to the development of 'subctance' of science that need to be 'upgraded' by UII's higher pesantren, either through formal forum such as the annual alumnus conference as well as informal forum through an application program that can be filled by all of its alumnus. This responsive and participatory approach from the grassroot model, according to the analysis of Thoyib (Thoyib, 2012) is very helpful to the quality assurance process that is continuously maintained and developed by UII Yogyakarta, including in this case for the existence of its higher pesantren, especially in ensuring the level of customer satisfaction in the curriculum products implemented during this time. 
The efforts to develop integrated curriculum with top down-bottom strategy which conducted by UII's excellent higher pesantren is implemented in every 4 years through 2 development forums in line with the progressive thinking of Beachaum and George $\mathrm{A}$ (Beauchamp and George A, 1992) in their book, The Curriculum Theory: First, forum of the rectorate meeting that involving the rector and vice rector I and III, director of higher pesantren, and caregivers. This forum is academically, according to researcher should be done at least as a 'preliminary guideline' in determining policies in general or specific about subtantive things that needed to be updated/refined in the curriculum of its higher pesantren, such as science clumps that become distingtion (uniqueness), standards of educators, standards of learners, or the standards of lecturing management in its higher pesantren. This is in line with the constructive thinking of Sanjaya (Sanjaya, 2009), which confirms that in the development of the curriculum, it is important to see the initial policy of the teaching in an institution. It is not another attempt to discord the 'institutional profile' and the future orientative goals of its educational program (Fathurrohman and Sulistyorini, 2014). In other words, a top down strategy in the curriculum development is used by its excellent higher pesantren to assert the ' taste image ' that it wants to develop.

Secondly, through the meeting forum of curriculum feasibility study of its excellent higher pesantren that involves the director of its higher pesantren, curriculum experts, caregivers, students and alumnus who framed in the form of higher pesantren curriculum development. In its implementation, the forum can be interpreted as a grassroots strategy or bottom up where the initiation of curriculum development emerged through a formal forum of 4 years which has been scheduled to be systemic way by its higher pesantren. So this forum can be said as a 'control forum' as well as 'improvements forum' to the extension of its excellent higher pesantren currriculum that has been implemented and perceived impact by both students and alumnus spread across the archipelago.

In one side, this strategy is important to be done as 'identity determination process' of the study program and one other side, to emphasize the value of distingtion (uniqueness) that is expected by the stakeholders of UII's excellent higher pesantren flagship on Especially. The institutional view was stated by Rembangy (Rembangy, 2015) and Lau (Lau, 2001) as the identity platform of the institution's specific and orientative curriculum. It is also described in the curriculum structure of its excellent higher pesantren as follows: 
Table.1. The IntegratedCurriculum of UII's Excellent Higher Pesantren

\begin{tabular}{lll}
\hline No & Competency aspects & Sks \\
\hline $\mathbf{1}$ & Linguistics & \\
\hline & a. Nahwu I & 2 \\
b. Nahwu II & 2 \\
c. Sharf & 2 \\
d. Qirâah al-Kitâb & 2 \\
e. Balâghah I & 2 \\
f. Balâghah II & 2 \\
g. Tarjamah & 2 \\
h. Ta'bir Syafawiy wa Tahririy & 2 \\
i. English Language I & 2 \\
j. English LanguageII & 2 \\
k. English LanguageIII & 4 \\
1. English LanguageIV & 4 \\
& & 4
\end{tabular}

\section{Stated capabilities}
a. Tafsir Ayat al-Ahkâm
b. Tafsir Maudhû'iy wa Tahlîliy
c. Hadits al-Ahkâm
d. Ushûl al-Fiqh I
e. Ushûl al-Fiqh II
f. Qawâ'id al-Fiqhiyyah
g. Masâil Fiqhiyyah fi al-Ibâdah 2
h. Masâil Fiqhiyyah fi al-Mu'âmalah 2
i. Masâil Fiqhiyyah fi al-Munâkahah wa al-Mawâris
k. Muqâranah fi al-Ushûl wa Hikmah at-Tasyri'
1. Ilmu Falak

2

2

2

2 


$\begin{array}{ll}\text { a. Ulûm al-Hadits } & 2 \\ \text { b. Ulûm al-Qur'an } & 2 \\ \text { c. Scientific Writing Method } & 2 \\ \text { d. Logic and philosophy of science } & 2 \\ \text { e. Final Task(Thesis) } & 4\end{array}$

2

2

2

4

\section{$4 \quad$ Da'wah Competence}

a. Fiqh ad-Dakwah

b. Public Speaking

c. Communication Psychology

d. Ushûl at-Tarbiyyah

2

e. Orientalism \& Cristianology

f. Ghozw al-Fikr

2

\section{Moral Competence}

a. Morals Learning

b. Sufism

c. Sirah An-Nabawiyyah

d. Aqîdah

2

2

2

2

\section{Total sks} 92

Nevertheless, at the level of strategy implementation, still found a weakness that is quite crucial that is the lack of engagement outsider users of the alumnus services in the process of developing their integrated curriculum. In fact, the user of the alumnus service is a direct user that related with competency owned by its alumnus. Therefore, without the involvement of these parties, the process of 'renewal' as well as the 'refinement' of its curriculum does not be maximal and comprehensive. In that context, the engagement of outsider (alumnus users service) is important and should be involved through a number of communicative forums and mechanisms, if the institution flagship of UII Yogyakarta is interested to get the curriculum development that is increasingly competitive forward. Or borrowing the language of Stark J.S. \& A. Thomas, in their book, Assessment and Program Evaluation, 'Customer is The First ' (Stark and Thomas, 2016). In other words, the customer must be a major reference in the development of an educational program of a classy institution. 
The development of integrated curriculum is essentially the 'demands' of global challenges as well as increasingly complex education competitions. Therefore, to ensure that development process is effectively required planning that mature against all needs as well as the organizational construction of institution itself, ranging from human resources, facilities and commitment to the excellent of innovation (Nurgiantoro, 2013). Or in simple language, completeness of systemic needs of educational institutions become crucial elements to the success of integrated curriculum development of an educational institution, including in this case what has been developed by UII's excellent higher pesantren.

The strategies model description of integrated curriculum development in UII's excellent higher pesantren is also based on the research findings supported by 5 main phases: (a). Setting the area plan of higher pesantren's curriculum for the dimension of university values; (b). Appointing parties who will be involved in the curriculum development process in this case representatives of the rectorate/vice rector 1 of academics and vice-rector III of student affairs, director and secretary of excellent higher pesantren, a number of its InternalExternal lecturers, alumnus, and students; (c). Establishing procedures to be pursued in formulating general and specific objectives, choosing content and learning experiences (courses, teaching materials, weights and spreads, allocation of time and distribution of courses, and schedules of teaching), as well as evaluation procedure. The entire procedure is listed in the guidance of education implementation of UII's excellent higher pesantren; (d). Implementing the curriculum with the level of understanding of lecturers as well as supporting means of teaching, whether it is activities (regular lecture in the class) such as the Arabic and English language lecture, research methodology, christology, Indonesian civilization study, and so on and also other extracurricular activities such as class of international debate on english and arabic language, class of scientific literature, and so on; and (e). Establishing curriculum evaluation directly related to design, implementation process and the results of its curriculum implementation as well as conversion system at university level conducted at the beginning and end of lecturing as a comprehensive control and repair effort (Anas, 2018).

Subtantively, seeing the fifth development stages designed by UII's excellent higher pesantren can be said that is very comprehensive because it involves many parties ranging from structural academics to professional academics, as well as supported by a system of mechanisms such as the curriculum drafting guidelines and its evaluation. It includes the contribution value of its higher pesantren curriculum that can not only be 'felt' internally by the excellent higher pesantren but also the university with a value conversion system because the standards of learning in the higher pesantren are viewed higher, such as the philosophy of science in university and its order, and so on. 
In an implementation, the five stages were according to the researcher is 'identical' with the idea of Beauchamp and George A (Beauchamp and George A, 1992). Although, there is little difference with the subtantive idea of Beauchamp especially on 'determination of the parties' aspect in the curriculum development process where in UII's excellent higher pesantren is more focused on the internal parties including its alumnus, while Beauchamp 'advocated' not only involving the internal parties broadly including alumnus, but it is also important to accommodate the idea and view of 'users' in order to strengthen the alignment of educational output with the wishes of its users. It is reinforced by the views of W. Ralph Tyler (Tyler, 2014) and Chu Ying Lu, et.al., (Lu et al., 2015), that alumnus is the real quality mirrors of curriculum products. Moreover, alumnus of UII's excellent higher pesantren has a relatively diverse profession and program expertise. The simple description of curriculum development model of UII's excellent higher pesantren can be seen in the following image. 
Figure3. The Model of Integrated Curriculum Development in Excellent Higher Pesantren of UII Yogyakarta

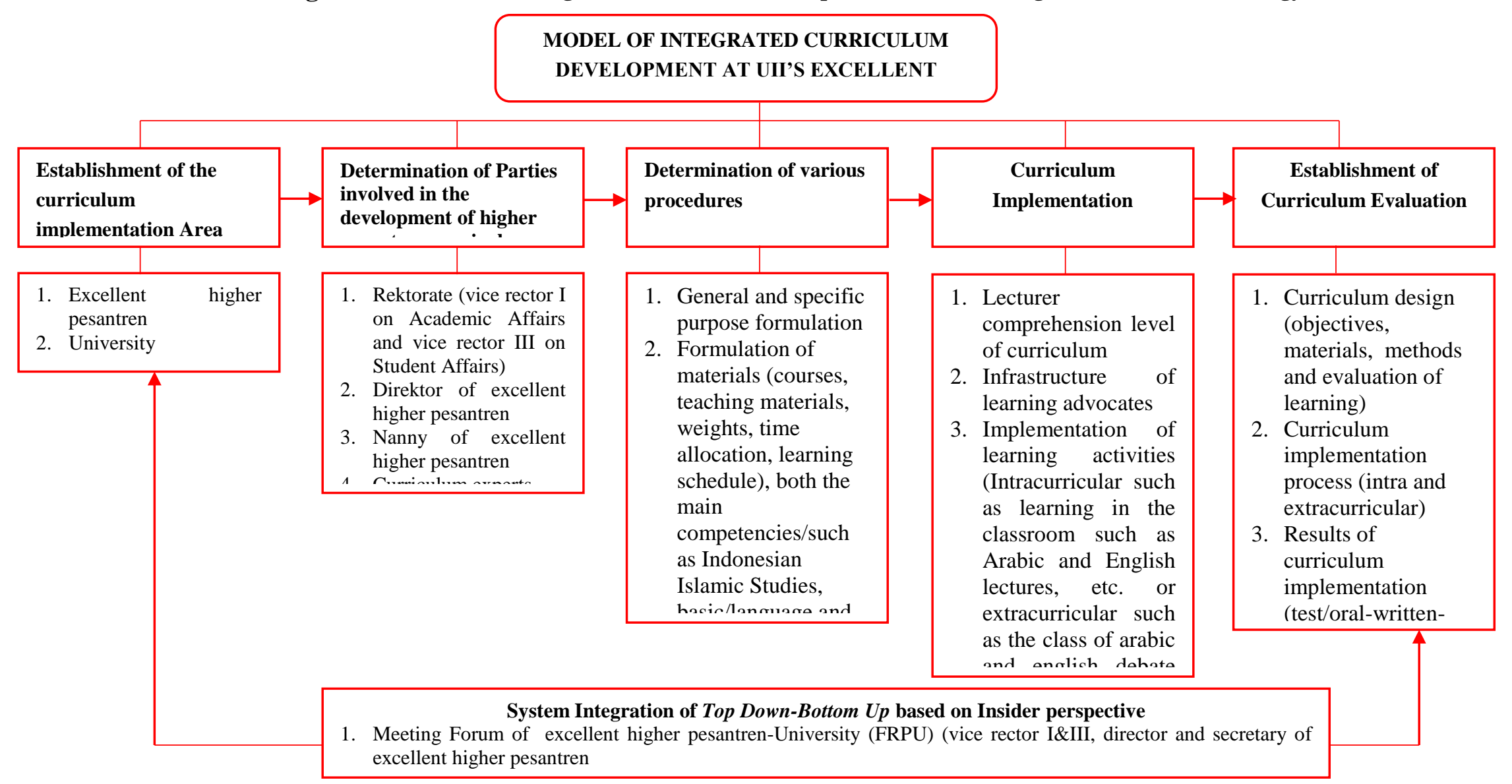




\section{Conclusion}

From the exposure of description and analysis above can be concluded as follows. First, the indigenous values in the integrated curriculum development of excellent higher pesantren of UII Yogyakarta to be in the Dharmabakti value of Pesantren University is oriented towards the candidate establishment of a 'progressive-inclusiveintegrative' moslem scholar personality. Secondly, the challenges of integrated curriculum development at its excellent higher pesantren include; (1) Alignment of the synergy of values between university and modern higher pesantren; (2) Institutionalization of university policy and higher pesantren oriented to the standards of policy determinant of its pesantren; (3) As well as integrating the curriculum products of university based on higher pesantren and community service. These challenges must be able to be answered by UII, in particular how to make a general course in the faculty to have a 'cohesion' with the curriculum of its higher pesantren that has remained an institutional problem.

Thirdly, the strategies of integrated curriculum development of its excellent higher pesantren, are implementing a top down and bottom up approachs at once involving a number of parties, namely rectorate, director, nanny, curriculum experts, faculty representatives, students and alumnus conducted every 4 years through 2 development forums namely: forum of rectorate meeting; As well as through the forum of meeting feasibility study of higher pesantren in the frame of excellent curriculum development that supported by 5 phases that are namely (1) Setting plan area of the integrated curriculum implementation with dimensional value of university; (2) Establishing the parties involved in the integrated curriculum development of its excellent higher pesantren; (3) Establishing procedures to be pursued in formulating objectives, content and learning experiences, as well as evaluation procedures used by higher pesantren; (4) Implementing the curriculum with the level of understanding of lecturers and supporting facilities in higher pesantren; and (5). Establishing a curriculum evaluation directly related to design, implementation process and the results of its curriculum implementation. Nevertheless, at the fifth stage, there is a point of deficiency that needs to be perfected, namely the necessity of strengthening 'outsider's perspective', especially the users of its higher pesantren's products (alumnus). Because so far the evaluation process is more focused on its internal pesantren stakeholders, that impressed less open minded to the needs of user community as the idea of Beauchamp. 


\section{REFERENCES}

Ajijola, A.D., 2012. Restructure of Islamic Education. Adam Publishers and Distributors, New Delhi.

Anas, M., 2018. Secretary of Excellent Islamic Higher Boarding School interview.

Arikunto, S., 2008. Prosedur Penelitian: Suatu Pendekatan Praktek. Rineka Cipta, Jakarta.

Asrofah, H., 2009. Kelembagaan Pesantren: Asal-Usul dan Perkembangan Pesantren di Jawa. Bagian Proyek Peningkatan Informasi Penelitian dan Diklat Keagamaan, Jakarta.

Azra, A., 2012. Pendidikan Islam: tradisi dan modernisasi menuju milenium baru. Logos Wacana Ilmu, Ciputat.

Ballantine, J.H., 2017. The Sociology of Education: A Systematic Analysis. Princeton-Hall, Inc., New Jersey.

Beauchamp, George A, 1992. Curriculum Theory. The KAGG Press, Wilmette. Illiois.

Bogdan, R.C., Biklen, S.K., 1996. Qualitative Research for Education: An Introduction to Theory and Methods. Aliyn dan Bacon, Boston.

Bruinessen, M. van, 1995. Kitab Kuning: Pesantren dan Tarekat. Pustaka, Bandung.

Document of UII Yogyakarta, 2017.

Fathurrohman, Sulistyorini, 2014. Implementasi Manajemen Peningkatan Mutu Pendidikan Islam: Peningkatan Lembaga Pendidikan Islam Secara Holistik, Praktek dan Teoritik. Teras, Yogyakarta.

Furchan, A., et. al, 2015. Pengembangan Kurikulum Berbasis Kompetensi di Perguruan Tinggi Agama Islam. Pustaka Pelajar, Yogyakarta.

Hardian, A.R., 2016. Perguruan Tinggi dan Pesantren: Potret Khazanah Peradaban Indonesia. Republika.

Lambert, J.P., 2019. "Curriculum Planning, Development, Implementation and Quality Promotion for Innovative Higher Education in UK". Journal of. Education Research. 17(2): 71-83.

Lau, D.C.-M., 2001. "Analysing The Curriculum Development Process: Three Models." Journal of Pedagogy, Culture, and Society. 11(2):29-44.

Lu, C.Y., Nguyen, Q., Ersin, O.H., 2015. "Active Student Engagement in Curriculum Development." American Journal of Pharmacetiucal Education. 79(2): 30-41. https://doi.org/10.5688/ajpe79230

Nurgiantoro, B., 2013. Dasar-dasar Pengembangan Kurikulum. BPFE, Yogyakarta.

Pratt, A.B., 2019. "Curriculum in Conflict: How African American and Indigenous Educational 
Thought Complicates The Hidden Curriculum." The Curriculum Journal. 21(1): 51-59.

Reeves, D.B., 2017. The Leader's Guide to Standars: A Blueprint for Educational Equity and Excellent. Jossey-Bass, San Francisco.

Rembangy, M., 2015. Pendidikan Islam Transformatif. Teras, Yogyakarta.

Sanjaya, W., 2009. Kurikulum dan Pembelajaran: Sebagai Referensi bagi Pendidik dalam Implementasi Pembelajaran yang Efektif dan Berkualitas. Kencana, Jakarta.

Sparapani, E.F., Perez, D.M.C., 2015. "Perspective on The Standardized Curriculum and Its Effect on Teaching and Learning." Journal of Education and Social Policy, 2(5): 78-87.

Stark, J.S., Thomas, A., 2016. Assessment and Program Evaluation. Simon \& Schuster Custom Publishing, New York.

Sukarji, Umiarso, 2014. Manajemen dalam Pendidikan Islam: Konstruksi Teoritis-Filosofis dalam Menemukan Kebermaknaan Pengelola pendidikan Islam. Mitra Wacana Media, Jakarta.

Sulistyo, H.S., 2015. Pesantren, Islam dan Radikalisme. Bintang, Yogyakarta.

Suyanto, 2018. Kyai of Excellent Islamic Higher Boarding School interview.

Thoyib, M., 2012. Manajemen Mutu Pendidikan Islam Kontemporer: Teori, Aksi dan Mutu Pendidikan dalam Konteks Internasionalisasi Pendidikan Indonesia. Kemenag RI, Jakarta.

Tyler, W.R., 2014. Paradigma Kurikulum dan Pembelajaran Antisipatoris: Masyarakat Global. Penterjemah.HM. Djunaidi Ghony dari Basic Principles of Curriculum and Instruction. Kutub Monar, Malang.

Wahid, A., 1984. Asal Usul Tradisi Keilmuan di Pesantren. J. Pesantren 6, 1-9.

Ziemek, M., 1992. Pesantren dalam Perubahan Sosial, terj. Butche B. Sundojo. P3M, Jakarta. 
